\title{
High Test Results
}

National Cancer Institute

\section{Source}

National Cancer Institute. High Test Results. NCI Thesaurus. Code C63122.

Test results provided by the device are too high or higher than expected. 